\title{
Business Day
}

National Cancer Institute

\section{Source}

National Cancer Institute. Business Day. NCI Thesaurus. Code C52592.

Any day a government or commercial enterprise is open and actively eng aged in the work of that enterprise. 